\section{D.T. Banda}

Dr. D.T. Banda, Justo Mwale University.

(orcid.org/0000-0001-9876-9886)

dtmbanda@gmail.com

\section{Banda}

Dr. L. Banda, Justo Mwale

University.

(orcid.org/0000-0001-7400-4803)

mbusad20le1969@gmail.com

\section{Blok}

Rev. M. Blok, Justo Mwale

University.

(orcid.org/0000-0002-0856-8819)

matthijsblok66@gmail.com

\section{Naidoo}

Prof. M. Naidoo, Department

of Philosophy, Systematic and

Practical Theology, University of

South Africa.

(orcid.org/0000-0001-8110-1636)

Naidom2@unisa.ac.za

DOI: http://dx.doi.

org/10.18820/23099089/actat. v40i2.09

ISSN: 1015-8758 (Print)

ISSN: 2309-9089 (Online)

Acta Theologica 2020

40(2):165-184

Date received:

22 June 2020

Date accepted:

19 September 2020

Date published:

18 December 2020

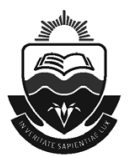

Published by the UFS

http://journals.ufs.ac.za/index.php/at

(C) Creative Commons

With Attribution (CC-BY)

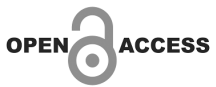

MINISTERIAL

FORMATION

FOR SERVICE:

INTEGRATIVE

THEOLOGICAL

EDUCATION AT

JUSTO MWALE

UNIVERSITY, ZAMBIA ${ }^{1}$

\section{ABSTRACT}

In ministerial training, effective integration of academic excellence, spiritual formation and vocational training is critical to produce holistically trained Christian leaders. This article positions integration as an educational approach that attempts to coordinate and synthesise the major learning dimension and can bring about significant learning, since it takes account of the lifeworld of the student and engages a custom-designed curriculum. This article reports on an empirical research project on integrative theological education at Justo Mwale University, Zambia. It reports on various dimensions within the formal and informal curriculum in the residential Bachelor of Theology programme. The article provides key findings and a discussion on the contextual and institutional challenges that shaped curriculum design. It reflects on the learning gained through this action research and concludes with strategies to move towards a more integrative model of theological education.

1 The research project received a grant from the Nagel Institute for the Study of World Christianity, an Institute of Calvin University, Grand Rapids, MI, USA, which was funded by the Templeton Religion Trust, Nassau, Bahamas. This research gratefully acknowledges the support of the Vice Chancellor, faculty, students and stakeholders of Justo Mwale University, Lusaka, Zambia. 


\section{INTRODUCTION}

Justo Mwale University (JMU), a Christian university in Lusaka, Zambia, was part of an Africa-wide research project from 2018 to 2020 on integrative theological education, together with the Baptist Theological College of Southern Africa (Naidoo 2020), and the Pentecost Theological Seminary in Ghana (Quampah \& Naidoo 2020). All case studies explored the idea of integration. First, how well the parts of the institution and curriculum are intentionally connected, and the rationale articulated for the interrelationships of experiences and, secondly, how best to move towards integrated education incorporating African values in terms of philosophy, world view, and pedagogy. $\mathrm{JMU}$ was selected to be part of the sample, as it is an accredited institution with the focus on research and had the research capacity to complete the project. The participation came at an opportune time when JMU was reviewing its curriculum and developing a strategic framework for the period 2019-2023. A decade ago, JMU (then Justo Mwale Theological University College, with nine other Reformed institutions in Africa) was privileged to be part of a research project on curriculum development, which found that

nearly all institutions used curricula copied and adapted from Western
institutions and added material on an ad-hoc basis. In many cases
there are no written outcomes for modules, no assessment plan and in
general a lack of quality control (Du Preez et al. 2013:5).

Research in Africa has consistently shown that there is a disconnect between the model of theological training and the local, contextual realities facing the church in Africa (Galgalo 2004; Jusu 2017). Yet institutions continue to use a less than relevant appropriate approach. This study sought to comprehend how JMU understands this concept and coordinates the major learning experiences in its programme, in order to foster the holistic development of students, namely the head, heart and hands. In education studies, integrated curriculum is described as "interwoven, connected, thematic, interdisciplinary, multidisciplinary, correlated, linked, and holistic in nature" (Beane 1997:32). Teachers purposefully plan strategies and learning experiences to facilitate and enhance learning across key learning areas. The need for an integrative approach is due to the disintegrated way in which African theological education is provided, especially the overt academic focus of theological education that leaves students unprepared for ministry in the community (Galgalo 2004; Jusu 2017). 


\section{BACKGROUND TO JUSTO MWALE UNIVERSITY}

JMU was initially a ministry of the Reformed Church in Zambia (RCZ) in 1940, It then moved the Theological College to Lusaka in 1969 to be closer to the newly established University of Zambia (UNZA) in the hope of upgrading its offerings. JMU is owned by the RCZ. It is ecumenical in terms of both the design of the curriculum and the governance of the institution. In 1975, the College was named after the first ordained Zambian minister in the RCZ, Rev. Justo Chokwe Mwale. With the decision to actively upgrade the training programmes, the RCZ also decided to make training facilities at the College available to other Reformed and Presbyterian churches in the region, which were invited to participate in the government of the College. Graduates of JMU now include students from mainly Reformed and Presbyterian churches in Zambia, Malawi, Zimbabwe, Botswana, Namibia, South Africa, and Mozambique. The Accrediting Council for Theological Education in Africa (ACTEA) accredited the Bachelor of Theology in 1997. The Zambian Higher Education Authority did likewise in 2016 and 2019, respectively. Justo Mwale became a University College in 2008 and a university in 2011, with the motto: Nditumikira Khristu (I Serve Christ). The revised vision - "to be a leading Christian University in Sub-Saharan Africa" - and its mission statement - "to provide quality, contextual, Christ-centred, holistic education that empowers persons to serve the church, academy and society in Sub Saharan Africa and beyond" - are the foundation of the JMU curricula. JMU currently has a School of Theology and Religion Studies and a School of Education. ${ }^{2}$

\subsection{Programme}

The programme reviewed is the four-year residential programme Bachelor of Theology. This programme currently offers 66 courses over four years, of which 14 Biblical courses, 18 Systematic Theology and Church History courses, 23 Practical Theology and Missiology courses, and nine Humanities and Development Studies courses, complemented by mandatory 90 hours weekend field education and five weeks field education over the first three years. Each year consists of three terms and each term has an average of five courses. Most of the courses expand the knowledge and skills of students over four years (horizontal integration) rather than yearly on different levels (vertical integration). ${ }^{3}$ The 32 courses in Biblical Studies, Systematic Theology

2 The school of Theology and Religion offers a four-year semi-residential programme Bachelor of Theology and a two-year semi-residential programme Christian Ministry. The School of Education includes Open and Distance Learning for Bachelor of Theology with Education and Master of Theology with Specialisation.

3 For a discussion on the three dimensions of vertical, horizontal and diagonal integration, see Cahalan (2011). 
and Church History form a cluster, as they are primarily biblical theologically oriented. The 32 courses in Practical Theology, Missiology, Humanities and Development Studies are a unit, as they are mainly practical theology oriented. The emphasis on both biblical and practical theological courses is a result of the strong Reformed conviction that doing theology should be rooted in Scripture and prepare for ministry.

Training consists of formal lectures, weekend field-education in Lusaka, and five weeks' field education throughout the nation over the first three years. Bishops or church councils evaluate the field education. These evaluations are submitted to JMU's fieldwork coordinator, who, in turn, compiles a consolidated report for all students. This report must be approved by Senate as part of the comprehensive evaluation of the student. Non-formally, JMU provides chaplaincy, weekly spiritual companionship, prayer meetings, chapel services, sports, and need-based counselling sessions that relate more to the hidden curriculum, whereby students interact with their peers, church members of nearby congregations, and families of members of full-time staff residing on campus.

The faculty consists of nine full-time members (three expatriates and six Africans) and 12 adjunct lecturers drawn from various churches and institutions of learning. In addition, six international guest lecturers visit annually. The student body averages 50 students per year, of whom the female students' average is eight per year in comparison to the majority of male students. This means 13 students per year group. The students are mostly Reformed (58\%) or Presbyterian (38\%), Charismatic $(2.5 \%)$, and Lutheran $(1.5 \%)$.

\section{THE RESEARCH PROJECT}

An empirical study was conducted to examine the academic and non-academic methods in which formation is being holistically fostered in the curriculum; to understand the contextual and institutional challenges that exist in terms of providing integrated formational education, and to indicate ways towards an integrative approach of JMU's ministerial formation. The theoretical framework is based on Cahalan's (2011) definition of integration as attempts to combine in one programme the three major dimensions of education: a cognitive or intellectual apprenticeship, pastoral skills development, and an apprenticeship of character or spiritual formation. A qualitative approach was used in this case study, coupled with action research, which is

a flexible research methodology uniquely suited to researching and supporting change. It integrates social research with exploratory action to promote development (Given \& Somekh 2008:4). 
In this method, the research team consisted of JMU staff members who were both observers and stakeholders in the outcome.

This action-research process involved interviews, a stakeholder workshop, and a faculty capacity-building workshop. Data was collected from 23 semistructured interviews: five interviews with academic staff involved in student formation to gauge the priority and alignment of the integrated focus in the educational programme; eight interviews randomly with third- and final-year students to understand their learning experiences and readiness for ministry, and six interviews randomly with graduates in the last five years to understand the value and relevance of learning received at JMU. Diversity in the sampling was a key factor. However, as only one female student was interviewed, four additional written interviews were collected from female students to enhance the data collection. In addition, data was collected from observations of various formational activities on campus, through an analysis of the curriculum and the mandate evident in JMU institutional documents such as the Constitution, policy and procedures, prospectus, and yearly manuals over the past five years. Overall triangulation was used to understand an integrated formational emphasis in more than one way to enable the researchers to view all aspects thereof. At all times, principles of research ethics were maintained with institutional permission from JMU to conduct the research, involving informed consent, confidentiality, anonymity, and the clarification of data management.

Data analysis and the formulation of themes was done, using open coding (Saldana 2009), first, manually where the researchers identified and labelled segments that give meaning and then using data analysis software ATLAS. ti v.8. A code list was generated with the help of data analysis support, with member checks conducted and themes were formulated and verified against the manual coding. The research team spent time understanding themes from actual educational practice. Emerging themes were discussed to search for contradictions and commonalities in the refinement process. Themes were shared with the broader community at a stakeholder workshop, hosted by the research project, where faculty, students, graduates, pastors, and members of the church board gathered to discuss the findings, to verify and provide additional reflections. The research team then discussed the feedback from this workshop for further refinement of themes, with additional focus-group discussions with students and staff. In addition, as part of this research, an expert in curriculum, developed from the Reformed tradition, held a capacitybuilding workshop for the faculty on core principles of integrated education to enable JMU to fully engage. 


\section{RESEARCH FINDINGS}

To align the research question of integration with the formal and informal curriculum, we only highlight findings that are relevant to the three learning dimensions: academic learning, pastoral skills development and spiritual formation, its integration, as well as the contextual and institutional challenges that shaped integration. The findings mentioned various themes pointing to the positive elements of the curriculum such as good relations between staff and students, the availability of staff due to close community interaction, and the engagement of the church in student formation. We present the findings that point to gaps in the JMU curriculum, in order to understand the nature of the problem and to work towards integrative strategies.

\subsection{Need for a broader curriculum}

A number of issues were highlighted regarding the formal curriculum. A key theme highlighted by students was the need for more courses relevant to their context:

Because of the fast changing social and religious context, we need courses to be brought on board dealing with issues like demonology, exorcism, Pentecostalism, conflict resolution and poverty.

This quote speaks to the lack of contextual relevance of what was learnt in relation to their work in the community. The research team acknowledged that special emphasis should be placed on African realities such as demon possession, deliverance, and poverty, in order to be relevant to the cultural context. In terms of engaging cultural norms, a student stated:

There are a lot of protocol matters in terms of dealing with certain people in the community; the Chiefs, Headmen, Political leaders. We did not learn these things and because these people are held in high esteem, any mistake of wrongly dealing with them is considered as dissent.

Students also requested courses that extended beyond church work, courses on entrepreneurship that could stimulate other streams of employment such as "mechanics, agriculture, carpentry or tailoring", while female students requested courses on gender.

Graduates, who are now active in ministry, also clearly expressed the need for a broader and culturally appropriate curriculum, as they now feel the challenge of applying learning in complex community situations:

Most books are written by Americans, thus difficult to apply to the context. When you come to the ground now to deal with the local people, there is a different understanding because the context is totally different. As 
a result, it becomes a problem to try to bring the information learnt at school to the level which the local people can comprehend clearly.

Learning from "elsewhere" is the reality of not having resources that address African realities. Most of the resources are from Western funders who invite the institution to choose textbooks from established publishers in their country. A great deal has been written about the dearth of African literature (Mugambi 2013; Kombo 2013) evidenced in JMU; its production, and accessing local material that attends to needs.

Regarding students' experience of learning in the formal curriculum, there was a high frequency for the theme of appropriate time allocation for courses. Students stated that:

There is need for more time to be allocated to a particular course, for example a student is required to take 10 courses in one term. The consequence is that the student will only pass through the course without much comprehension of the course content.

Many content-heavy courses also impact on the integration of learning, as students become overwhelmed by academic learning and struggle to incorporate learning in all the different roles and activities. Another student stated:

The other thing that requires improvement is time allocation for the course. For example, a course is taught in ten weeks, I feel the time is short; it is not possible for a student to acquire enough knowledge in ten weeks. In some instances when a course is taught by a Guest Lecturer, the same course is taken in two weeks, a course meant for ten weeks.

Church representatives also perceive that the curriculum is overloaded. They argue that students do not need so many courses. They found that it was better to teach them skills and to learn to think theologically and missionally rather than to try to know everything.

\subsection{Engaging relationships in vocational training}

In terms of vocational training, opportunities were revealed for church ministry and pastors who assist JMU in the assessment of students through reports. This theme showed a need for greater integration in pastoral skills development, as requested by all stakeholders, church representatives, members of staff, and students:

engaging relationships between JMU, supervisors and students including termly follow ups. JMU needs to learn from supervisors and, in turn, to equip them. Supervisors expressed the need to engage the school and the students prior to the student reporting for vocational 
training. And students want to know the feedback from supervisors before the evaluation form will be sent to JMU's field coordinator.

In current practice, students risk going mechanically through the fieldwork learning, where the resident minister/supervisor merely ticks the box instead of helping to shape the character of the student. Valuable learning opportunities are lost when there is hardly any discussion of what the student learnt, no reflection takes place, and no further discussions are held in the classroom. In practical work, it is assumed that learning has taken place when it may not have happened. In each area of engagement, from ministry supervisors to JMU faculty to students, current procedures need to be revised, in order to ensure that real learning takes place.

In the findings, members of staff and current students stated that supervision should not primarily focus on doing [tasks] but on being [the self of the student and the personal qualities of the student]. A key principle of integration is that faculty should take the time to get to know the persons they are teaching. A holistic approach argues that the faculty should constantly observe all their practices in order to prepare students to be whole persons. As such, students will learn to involve all aspects of their being in every action and situation they encounter.

\subsection{Spiritual formation should be reprioritised as a core task}

JMU had planned activities such as chapel services, communal prayers, and daily devotions to nurture spirituality in students. Some lecturers agreed

that there is no balance on this matter as most of the time the academic part takes central stage due to the need to fulfil the academic requirements by the regulating authorities.

Students also felt that academic excellence is prioritised at the expense of spirituality. They emphasised that

JMU should not compromise on the theological basis and content and that the academic goals are still useful and helpful, but meanwhile they underline that spirituality is an unmet hunger.

This aligns with the observation of the students' wives who also live on campus:

When coming at JMU from congregations, the spiritual level was high. We came with a zeal, but within a year we feel that this zeal is less now. There are the 'routine' things like chapel, Wednesday prayers and Sunday evening prayers. You go there because you have to be there, 
but it has not really impact because it is just preaching of the word, that's all. As one graduates the spiritual life is low and we have to start afresh.

Students at JMU are eager to serve the Lord with enthusiasm; however, the structured way of communal spiritual life can be part of the problem if it is not offered in more intentional ways. Students learn critical thinking and hermeneutic skills when interrogating scriptures and they are expected to become conscious and reflective in their spirituality, only if these links are deliberately made to support integration. Students identified "a gap on personal spiritual formation", stating

I would have loved that a student be assigned to a particular mentor to assist in his or her spiritual growth throughout the period of training, Currently, the task is assigned to the chaplaincy committee, I feel the process is not adequate.

The research team highlighted that attention must be paid to this theme, considering that Africans are inherently spiritual; it has to do with our relationship with God, our neighbours, creation, and the invisible world. Spirituality, therefore, has to be integrated in all courses and be reprioritised as the core task.

\subsection{Tensions of living in community}

This theme involving community life spoke to the "non-academic" methods or hidden curriculum where a significant amount of integration happens. If what is taught in the classroom or the espoused values by the community are not lived out, students experience cognitive dissonance, and learning is not integrated. Issues were raised that undermine minority voices and instances of discrimination on gender, denominational affiliation, and culture. A female student revealed that

[t]he students think that I am a weaker vessel in everything, sometimes male students look down upon female and seem not to believe that God can use a woman in ministry. When it comes to staff, there is only one female lecturer. I have never heard of any female theologian being offered a higher position at this institution.

This quotation highlighted that female students do not always feel that they are seen and heard, based on their God-given capacities, adding to their being marginalised in the community. Their identity as women is not valued in the learning environment and this has a negative impact on their integration of learning. In this hidden curriculum, male students perpetuate discriminatory patriarchal attitudes towards women and theological education does not "empower" as the JMU mission statement claims. This needs attention. 
As an interdenominational institution, JMU enrols students from subSaharan Africa who have a different education system, language of instruction, and attire. While trying to navigate around cultural diversity in the community, $\mathrm{JMU}$ faces the challenge of the dominant represented denomination such as the RCZ and is perceived to be suppressing the minority in terms of conduct and practice. Another example of tensions in the community is church affiliation. Students from denominations other than the Reformed churches initially feel "stigmatised", because "any contribution was perceived as false". Students attest that they "compete for which denomination is better instead of helping each other to listen to God speaking to us". According to members of staff, diverse cultural differences are also a challenge.

\section{DISCUSSION}

Making sense of the findings involves attaching meaning and interpretations to the findings and identifying the factors that contribute to disintegration. JMU has a well-articulated educational philosophy, with focused goals on the three learning dimensions together with the awareness of the need for both a solid theological foundation and the sociocultural relevance of learning. Yet, at the same time, key themes emerged that impact on integrative learning: the need for a broader curriculum; engaging relationships in skills development; the prioritisation of spiritual formation, and attention to community life. These contradictions in the findings need further exploration and attention. This will take more time than the time frame of this research project. However, some analysis and insights are offered based on the acquired learnings on integration.

A key principle of integration is the philosophical coherence of the curriculum, when all stakeholders (staff, faculty, church leaders, and students) are coherently committed to a known educational philosophy. When this is in place, all efforts in the learning environment will be intentional to avoid fragmentation and unintended contradictions. As Cahalan's (2011) definition states, integration involves attempts to bring together the three major dimensions of education. It does not suffice to simply have these three dimensions, as in the case of JMU, but rather to create connections or interlinking between learning dimensions. It would be instructive for the JMU faculty to workshop its mission statement that claims "holistic" education and ensure that its educational philosophy is indeed aligned to its mission and curriculum, so that learning from one area is linked to others, making integration self-evident. Nevertheless, this is not an easy task, especially in a university context with the eventual crosspollination of courses into the Humanities. The faculty are also overburdened with church responsibilities and need professional support. A faculty member commented: 


\begin{abstract}
But I need to admit that sometimes this integration is not consciously done due to the fact that we lecturers need some capacity building on the integration in curriculum.
\end{abstract}

Regarding the formal curriculum, we found that, with the reports on heavy workload and the marginalisation of spiritual formation, academic learning was prioritised, where a significant amount of time was spent on exposing the student to theories and teaching in major theological areas. We note that, in the Reformed tradition, the "ongoing dilemma has been how to reconcile the pure academic and the pure professional purposes of theological education" (Cole 2009:1). Nevertheless, for integrative learning, there needs to be "space" to reflect and consider how one is becoming with the new learning acquired. Activity and busyness are valued in a tradition that has a strong Protestant work ethic. At the same time, training institutions are always reluctant to reduce the workload, with apparent pressure from accreditation bodies. This results in learning that is rarely integrative for students and supports the claim that theological education is more about credentials than real learning (Mugambi 2013).

The need for a broader curriculum in this study arises from using a traditional Western curriculum and epistemologies where issues at stake in sub-Saharan Africa are barely addressed. This more compartmental and foreign approach suggests that it is the student's responsibility to bring the pieces together and to contextualise what they have learned in the societies in which they live. In JMU, this engagement is aggravated by the Western support of theological education, as Kombo (2013:106) states: "besides legally owning the institutions, African churches never really supported the theological colleges". Hence, foreign missions are still major funders who influence the agenda. Few question this dominant epistemological import, possibly because "colonized minds and education systems ... are more difficult to identify, resist and transform" (Androas 2012:6). Such form of the curriculum and such type of learning materials have rightly provoked the cry for Africanisation of the curriculum (Galgalo 2004; Maluleke 2005:489). Still, the dialectic at JMU is wanting to maintain the Reformed-Presbyterian identity and to be relevant by engaging global trends (Venter 1999:36, 38) to be part of a worldwide, dynamic, pluralist context. In this instance, we find a tension between guarding and preserving the church tradition that maintains the status quo, while needing to innovate, involving a "critical reassessment of tradition" (Cole 2008:1). This may entail a broader discussion on the Reformed church and theology in Africa. Nevertheless, for this study, integration speaks about meaningful learning that is learnt from a world view perspective. To find more appropriate content, Pali (2017:9) mentions inculturation of the gospel into the African world view so as to do away with the ambivalence in traditional culture: 
The church in Africa has fallen into a trap of uncritical acceptance of the church doctrines and practices from the mother church. This ended up by creating a dual spiritual lifestyle and doing religious practises that are foreign to one's culture.

Pali (2017:9) mentions inculturation as a form of "facilitating indigenisation of the gospel into culture and the Christianisation of culture". JMU needs to consider African culture (values and norms in the African context) and African traditional religion (beliefs, practices, and the way of life of the African peoples in relation to a supreme being and their ancestors), as we construct an integrative theological education curriculum. Maluleke (2005:489) makes an elaborate call for a serious consideration of the African traditional religion and culture in African theological enterprise:

\begin{abstract}
It seems to me that until African theology takes African religion and culture seriously, the discussion will continue to be artificial and patronizing. The increasingly pluralistic context in Africa demands that we 'listen' to other religions more carefully and more respectfully, without ceasing to be committed Christians ourselves and yet without a hidden evangelistic motive.
\end{abstract}

By implication, therefore, an integrative theological curriculum at JMU has to be constructed from the premise of a constellation of multicultural and multireligious African realities within which students are educated and in which they are expected to do ministry. In addition, the traditional heritage (established traditions of the church such as the church's teachings and confessions) needs to be revisited; theological and historical disciplines need to be contextualised to enhance African values and give life to the church's witness and mission to the world. With advanced scholarship already on postcoloniality, Nel (2018:4) states that the development of a curriculum for theological training requires attention to

interculturality and inclusivity, processes of decolonisation that place Africa at the core, the ways in which and places where knowledge is produced.

In addition, the need for a broader contextual curriculum is also related to the changing nature of the role of the church in Zambian society, the multiple roles of a pastor, and the demanding socio-religious micro, meso and macro context (Mbillah 2004; Kaunda 2016:115). Above all, pastors have to survive in a deteriorating economy and an environment vulnerable to natural disasters, where most of the congregants are not able to pay them. Instead, they plead for their intervention when crops do not yield well. Pastors have to compete with other ministers and those on television, adding to the pressure to perform. What pastors need is culturally relevant and entrepreneurial 
leadership training (De Wet 2015), which should be attended to by JMU. Otherwise, students feel pushed to the periphery. In the competitive higher education environment where commercialisation of theological education (Naidoo 2017) is a reality, more relevant courses add credibility.

In spite of the evangelical-pietist Reformed approach to spiritual formation, it is not meeting the personal spiritual needs of students. We note that African spirituality is not compartmentalised but involves all of life. Spirituality requires a broader conceptualisation to include African cultural ways of being. Research indicates that the post-modern search is "for new ways of living, life-giving identities, and alternative ways of expressing these identities" (Kaunda 2016:115). Deeper spiritual formation is also influenced by NeoCharismatic movements, with a strong emphasis on experience, immediate results, and a personal relationship with God (Hoekema 1994). In addition, engaging relationships between JMU, supervisors and students seems to be nurtured by the wider societal cry for democracy and transparency: people want to be heard and to be informed. To refocus spirituality at JMU will require designing credit-bearing spiritual formation, which is challenged by accreditation demands (Emedi 2013:1070). Accreditation highlights how secularism encroaches the holy space and creates an institutional identity crisis (Mwale \& Chita 2017). Yet faculty needs more capacity to engage the developmental agenda of formation (Naidoo 2011:122), in order to nurture more engaging spirituality.

Issues in the hidden curriculum affect trust and mistrust and openness or closeness and is central to integrative learning; the learning climate, relationship between teachers and students and between students all contribute to the integration of learning. Tendencies of undermining minority voices, female students, international students and those from Pentecostal and Independent churches were not fully embraced and listened to. Being predominantly male and mostly belonging to one denomination, JMU is constantly tempted to nurture a sense of insecurity for those of different gender and church denomination. What adds to the gender marginalisation is that the composition of the faculty is strongly related to the fact that JMU was established as a training institution of the RCZ and that, until 2006, lecturers, with one exception, were only from the Free State Synod of the Dutch Reformed Church (DRC) in South Africa, and none of them was female. Although JMU's non-discriminatory nature includes gender, in terms of teaching staff and enrolment of students, JMU's residential programme Bachelor of Theology has only one female lecturer and only three female students were registered over the past three years. At least three elements seem to influence this reality: the level of education of women, the worldwide position of women in Reformed-Presbyterian churches, and the philosophy that 
good African women who are looked up to as examples, are those who do not complain, and who accept their situation stoically (Djomhoue 2013:642).

There is the push for a more equal society that strives for (gender) equality, justice, and the empowerment of the marginalised. This, however, is often still utopia. There are also issues of cultural values and it seems that being part of the dominant culture is the way to go (Ngulube 1997:87; Banda 2019:94). It nurtures a sense of insecurity for those who represent minority voices. Ethnicity is a huge challenge in African theological education, whether it is acknowledged or not (Mugambi 2013). This position of the dominant culture is also noted in teaching and learning. Lecturers might exclusively teach knowledge and supervisors might be belittling students: "This is just a student" or "I am the minister here". Conversely, students sometimes lack a teachable spirit and behave disrespectfully. Both, however, are in conflict with the African values of communalism, cooperation, and diplomacy that emphasise personal well-being within the common good. Other pitfalls in our relationships include the search for applause; less preparedness to handle criticism, and the use of power to maintain the status quo instead of empowering people to serve and be served (Knoetze 2015:172-173). Whether belonging to a minority or to a majority, actions that do not affirm our values at JMU are an obstacle. These issues of broader culture and institutional culture highlight how the gospel is to be lived out institutionally, which impacts on how learning is integrated.

With all the investment (Stuebing 1999; Venter 1999; Zulu 2001; Du Preez et al 2013) over the years in curriculum development initiatives and the notable upgrades from a University College to a fully-fledged Christian University, this integrative approach to educational practice can make the most impactful difference, as it merges learning, life, and the personal appropriation of theological concepts.

\section{CURRICULAR INTERVENTIONS MOVING FORWARD}

From the findings and analysis of this study, we established that there is a disconnect between what JMU intends to achieve through its training and what students and stakeholders perceive. Even though JMU is aware of integration, as the word "holistic" is a goal in the current mission statement, more intention is needed. As an action research project, it was important to help institutions understand the nature of the issue, so that they have the awareness and needed information to do something about it. As a helpful way forward, the research team suggested an integrative motif based on a trinitarian-missional and communal conceptualisation that can hold together 
all that needs to be achieved. This model should reflect loving relationships, solidarity, unity in diversity and, above all, correlation and inclusivity. It should also include the African values of holism, wisdom, and respect. This motif could be developed corporately to articulate a theological and educational philosophy for education that will be owned by all as a blueprint for future teaching and learning. The goals created should reflect the kind of integration we want to achieve in students, with the necessary structures and resources to achieve these. Although curriculum changes cannot be finalised immediately, as this is a communal journey, some short-term and long-term commitments have been made that include the following:

- Pursuing a contextually more appropriate curriculum, by placing more emphasis on African realities, skills for entrepreneurship, and the interrelationship between theological disciplines through interdisciplinary thematic courses.

- Fostering relationships between staff, students, and supervisors, by enhancing transparency and accountability in learning outcomes, values and assessment of vocational training in local churches.

- Shaping the "being" of the students, by striking a balance between the head, the heart, and the hands.

- Valuing unity in diversity in community life, by considering all voices.

Short-term curricular changes include a course on entrepreneurship, including a visit to a company in order to experience the opportunities and challenges of doing small-scale business upon which, at a later stage in the course, will be reflected from the existing literature. The 2020 curriculum also includes a course on the HIVIAIDS pandemic in sub-Saharan Africa. Based on the conviction that people living with HIVIAIDS are subjects of theological interpretation, the course deliberately enables students to meet people living with HIVIAIDS. These learning experiences interact in a critical conversation with existing literature on discrimination and stigmatisation of people living with HIVIAIDS. The 2020 curriculum will also include an interdisciplinary thematic course for first-, second- and third-year students on a specific contextual contemporary topic, followed by a fellowship meal, where multiple lecturers, each from his/her own field, deliver content followed by interactive workshops. The course implements the African values of wisdom, respect, and holism, by incorporating the wisdom of different members of staff and students, by enhancing mutual respect among students of different years, by fostering the integration of theological disciplines, and by experiencing the value of engaging relationships.

Long-term interventions involve striking a balance between the head, the heart, and the hands in both pastoral supervision of learning and 
spiritual formation of students. In the next three to five years, a supervision system will be put in place. Like the African three-legged stool, it considers triangulation to be characteristic for student evaluation, both when it comes to joint participation of the three parties concerned in evaluation (lecturers, students and representatives of the church), as well as by striking a balance between the three interrelated aspects of evaluation (knowledge, practice and the self). Group work will be part and parcel of assessment; hence, fostering collaborative and communitarian education. Since a forest consists of individual plants, personal assignments will be the counterpart of group work evaluations. In spiritual formation, goals will be revisited, by providing a platform in which various interactive spiritual formational practices are employed. Whilst not wanting to overregulate spiritual formation, space will be created in which we develop formational rhythms such as quiet and reflection times, including, if desired, an opportunity to share the inward experiences resulting from these interventions.

In addition, attention must be paid to the hidden curriculum, in order to create a space for minority voices, while valuing unity in diversity that "profoundly impacts on the spiritual, academic and professional formation of students" (Naidoo 2015:80). In the next three to five years, we will enhance the sense of belonging to the JMU community by means of regular social interactions, fellowship meals, and holy communion celebrations, where students and staff sit side by side. We equally adopt from affirmative theories, by lobbying in our churches and staff committees to deliberately reserve certain positions for women and representatives of churches other than Reformed-Presbyterian. We deliberately recommend that, out of every two positions that fall vacant in the next three to five years, one should be given to a suitably qualified female. Out of every three students enrolled by churches for JMU's Bachelor of Theology programme, one should be a female. In the next one to three years, we also plan to reclaim the pre-theology training for women who do not yet meet all the entrance requirements specified by ACTEA and the Zambian Higher Education Authority.

Guiding principles in the above curricular changes are "the concept of empowering servant leadership" (Hendriks 2017:156) and "downward mobility" (Nouwen 2007:20), both signs of putting the other before self. These qualities "are less about the explicit curriculum than the implicit curriculum" (Jusu 2017:207), and perfectly embody the African values of wisdom, respect, and holism.

\section{CONCLUSION}

This research project provided an opportunity to explore what integration could mean for JMU and it questioned the status quo of the inherited curricular 
structures. It taught us not to take things for granted, to acknowledge the complexity of providing holistic theological, vocational and spiritual training, and to further sharpen integrative theological education grounded in African values. This research revealed different shortfalls that served as a catalyst to now reflect deeply on what integration could mean more expansively. Moving forward, it involves a longer collaborative journey to create integrative learning in collaboration with all stakeholders that can bring significant learning and transformation, so that students can confidently do the Christian work. This is what JMU's Bachelor of Theology programme intends to be: ministerial formation for service.

\section{BIBLIOGRAPHY}

ANDRAOS, M.E.

2012. Engaging diversity in teaching religion and theology: An intercultural, decolonial epistemic perspective. Teaching Theology and Religion 15(1):3-15. https:// doi.org/10.1111/j.1467-9647.2011.00755.x

BANDA, D.T.

2019. New Testament interpretation and African culture. Selections from 1 Corinthians. Beau Bassin, Mauritius: Lap Lambert Academic Publishing.

BEANE, J.A.

1997. Curriculum integration. Designing the core of democratic education. New York: Teachers' College Press.

CAHALAN, K.A.

2011. Integration in theological education. In: B.J. Miller-McLemore (ed.), The WileyBlackwell companion to practical theology $1^{\text {st }}$ edition (Oxford: Blackwell Publishing Ltd), pp. 386-395. https://doi.org/10.1002/9781444345742.ch37

COLE, V.B.

2009. Reformed theology and theological education in Africa. Paper presented at the Global Theological Education Conference, Jakarta, Indonesia, 21-23 March 2009. [Online]. Retrieved from: http://wrfnet.org/resources/2009/04/ reformed-theology-and-theological-education-africa\#: :text=REFORMED\%20 THEOLOGY\%20AND\%20THEOLOGICAL \% 20EDUCATION\% 20 IN $\% 20$ AFRICA \%20Paper, 2009\%20by $\% 20$ Professor $\% 20$ Victor $\% 20$ Babajide $\% 20$ Cole\%20Nairobi\%2C\%20Kenya [12 June 2020].

DE WeT, C.L.

2015. Entrepreneurial leadership training and theological education. In: M. Naidoo (ed.), Contested issues in training ministers in South Africa (Stellenbosch: Sun Press), pp. 127-141. 


\section{DJomhoue, $P$.}

2013. Mainstreaming gender in theological institutions in francophone Africa. Perspectives from Cameroon. In: I.A. Phiri \& D. Werner (eds), Handbook of theological education in Africa (Eugene, OR: Wipf \& Stock, Regnum Studies in Global Christianity), pp. 639-646.

Du Preez, K.P., Hendriks, H.J. \& CARL, A.E. 2013. Research into curriculum development at ten theological institutions of reformed tradition in sub-SaharanAfrica linked to NetACT. Nederduits Gereformeerde Teologiese Tydskrif 54(3\&4):1-14. https://doi.org/10.5952/54-3-4-374

\section{EMEDI, P.}

2013. ACTEA and quality assurance in evangelical theological education in Africa. In: I.A. Phiri \& D. Werner (eds), Handbook of theological education in Africa (Eugene, OR: Wipf \& Stock, Regnum Studies in Global Christianity), pp. 1064-1074.

GALGALO, J.D.

2004. The teaching of theology in Africa: Some reflections on sources, methods and curriculum. In: G. LeMarquand \& J.D. Galgalo (ed.), Theological education in contemporary Africa (Eldoret: Zapf Chancery), pp. 5-27. https://doi.org/10.2307/j. ctvgc5zxw.4

GiveN, L.M. \& SOMEKH, B. (EDS)

2008. Action research. The Sage encyclopaedia of qualitative research methods. Los Angeles, CA: Sage Publications. https://doi.org/10.4135/9781412963909

HENDRIKS, H.J.

2017. Empowering leadership. A new dawn in African Christian leadership. In: R.J. Priest \& K. Barine (eds), African Christian leadership. Realities, opportunities, and impact (Maryknoll, NY: Orbis Books), pp. 155-171.

HoEkemA, A.A.

1994. Saved by grace. Grand Rapids, MI: Wm B. Eerdmans.

JusU, J.

2017. Developing transformational leaders. Curricula implications from the African leadership study. In: R.J. Priest \& K. Barine (eds), African Christian leadership. Realities, opportunities, and impact (Maryknoll, NY: Orbis Books), pp. 199-213.

KAUNDA, C.J.

2016. Checking out the future. A perspective from African theological education. International Review of Mission 105(1):113-130. https://doi.org/10.1111/irom.12120

KNOETZE, J.J.

2015. Perspectives on family and youth ministry embedded in the missio Dei An African perspective. In die Skriflig 49(1):166-174. https://doi.org/10.4102/ids. v49i1.1874 
Комво, J.

2013. The past and presence of Christian theology in African universities. In: I.S. Phiri

\& D. Werner (eds), Handbook of theological education in Africa (Pietermaritzburg: Cluster Publications), pp. 100-107.

MALULEKE, T.S.

2005. African theology. In: D.F. Ford \& R. Muers (eds), The modern theologians. An introduction to Christian theology since 1918. 3rd edition. (Oxford: Blackwell Publishing Ltd), pp. 485-501.

MBILLAH, J.A.

2004. Christian theological education in the context of the religiously pluralistic continent of Africa. In: G. LeMarquand \& J.D. Galgalo (ed.), Theological education in contemporary Africa (Eldoret: Zapf Chancery), pp. 167-179. https://doi. org/10.2307/j.ctvgc5zxw.12

MugAmBI, J.N.K.

2013. The future of theological education in Africa and the challenges it faces. In: I.S. Phiri \& D. Werner (eds), Handbook of theological education in Africa (Pietermaritzburg: Cluster Publications), pp. 117-125.

Mwale, N. \& ChitA, J.

2017. Navigating through institutional identity in the context of a transformed United Church of Zambia University College in Zambia. HTS Theological Studies 73(3):17. https://doi.org/10.4102/hts.v73i3.4569

NAIDOO, M.

2011. An empirical study on spiritual formation at protestant theological training institutions in South Africa. Religion \& Theology 18(1-2):118-146. https://doi. org/10.1163/157430111X613692

2015. Dealing with the other. Managing diversity in theological education. In: M. Naidoo (ed.), Contested issues in training ministers in South Africa (Stellenbosch: Sun Press), pp. 71-83. https://doi.org/10.18820/9780992236014

2017. The globalising effect of commercialisation and commodification in African theological education. HTS Theological Studies 73(3):1-8. https://doi.org/10.4102/ hts.v73i3.4577

2020. Integrative ministerial training: A case-study in the Baptist tradition of South Africa. Acta Theologica 40(2):261-280.

NELL, I.A.

2018. We know to whom we belong? The drama of ministerial practice in a postcolonial African context. Verbum et Ecclesia 39(1):1-8. https://doi.org/10.4102/ ve.v39i1.1822 
NGulube, N.M.J.

1997. Culture and development. Lusaka: ZEPH.

NOUWEN, H.J.M.

2007. The selfless way of Christ. Downward mobility and the spiritual way of Christ. Maryknoll, NY: Orbis Books.

PALI, K.J.

2017. Theological reflections on the ministerial challenges of the Dutch Reformed Church in Africa in the Orange Free State in post-apartheid South Africa. HTS Theological Studies 73(2):1-12. https://doi.org/10.4102/hts.v73i2.4666

QUAMPAH, D. \& NAIDOO, M.

2020. Pursuing the ideal of integration in Pentecostal theological education: A case study of Pentecost Theological Seminary in Ghana .Acta Theologica 40(2):300-321.

SALDANA, J.

2009. An introduction to codes and coding. The coding manual for qualitative researchers. Thousand Oaks, CA: Sage Publications.

Stuebing, R.W.

1999. Training for godliness in African theological education. Ndola: ACTEA.

VENTER, R.

1999. Justo Mwale Theological College. A story of theological education in Zambia towards the third millennium. Theological Forum 27(3):29-40.

ZULU, E.

2001. An African response to modernism. In: H.J. Hendriks, D.A. Luidens, R.J. Nemeth, C.E. Smidt \& H. Stoffels (eds), Reformed encounters with modernity. Perspectives from three continents (Cape Town: print24.com, Conference Proceedings of the International Society for the Study of Reformed Communities), pp. 4-10.

Keywords

Curriculum integration

Zambian theological education

Ministerial formation

African values
Trefwoorde

Integrasie van kurrikulum

Zambiese teologiese opleiding

Bedieningsvorming

Afrika waardes 